\title{
Deferoxamine ameliorates adipocyte dysfunction by modulating iron metabolism in ob/ob mice
}

\author{
Hong-Fa Yan*, Zhao-Yu Liu*, Zhi-Ang Guan and Chuang Guo \\ College of Life and Health Sciences, Northeastern University, Shenyang, China \\ Correspondence should be addressed to C Guo: guoc@mail.neu.edu.cn \\ *(H-F Yan and Z-Y Liu contributed equally to this work)
}

\begin{abstract}
Objective: The mechanisms underlying obesity and anti-obesity processes have garnered remarkable attention as potential therapeutic targets for obesity-associated metabolic syndromes. Our prior work has shown the healing efficacy of iron reduction therapies for hepatic steatosis in a rodent model of diabetes and obesity. In this study, we investigated how iron depletion by deferoxamine (DFO) affected adipocyte dysfunction in the epididymal adipose tissues of ob/ob mice.

Methods: Male ob/ob mice were assigned to either a vehicle-treated or DFO-treated group. DFO (100 mg/kg body weight) was injected intraperitoneally for 15 days.

Results: We confirmed that iron deposits were statistically increased in the epididymal fat pad of 26-week-old ob/ob mice compared with wild-type (WT) mice. DFO significantly improved vital parameters of adipose tissue biology by reducing reactive oxygen species and inflammatory marker (TNF $\alpha$, IL-2, IL-6, and Hepcidin) secretion, by increasing the levels of antioxidant enzymes, hypoxia-inducible factor- $1 \alpha$ (HIF-1 $\alpha$ ) and HIF- $1 \alpha$-targeted proteins, and by altering adipocytic iron-, glucose- and lipid-associated metabolism proteins. Meanwhile, hypertrophic adipocytes were decreased in size, and insulin signaling pathway-related proteins were also activated after 15 days of DFO treatment.

Conclusions: These findings suggest that dysfunctional iron homeostasis contributes to the pathophysiology of obesity and insulin resistance in adipose tissues of ob/ob mice. Further investigation is required to develop safe iron chelators as effective treatment strategies against obesity, with potential for rapid clinical application.
\end{abstract}

\author{
Key Words \\ - obesity \\ - iron \\ - insulin resistance \\ - adipose tissue
}

\section{Introduction}

Type 2 diabetes mellitus (T2DM) is becoming one of the most pressing health issues facing society. Although T2DM is well described in terms of its hallmarks, namely insulin resistance and chronic hyperglycemia, the factors responsible for T2DM progression remain largely unknown. It is well accepted that the most reliable predictor for the disease is obesity (1). Therefore, antiobesity effects have been heavily examined as potential therapeutic targets for T2DM in current healthcare research $(2,3)$.

For obesity prevention, most of the interest in developing alternativestrategies targeting related processes, namely glucose transport and intake, differentiation of adipogenesis, suppression of inflammation and changes in the immune response, is centered around lifestyle modification and pharmacological intervention $(2,3)$, http://www.endocrineconnections.org https://doi.org/10.1530/EC-18-0054 (c) 2018 The authors Published by Bioscientifica Ltd

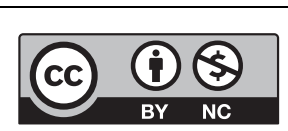

This work is licensed under a Creative Commons Attribution-NonCommercial 4.0 International License.
Endocrine Connections (2018) 7, 604-616 
although anti-diabetic drugs and insulin are not generally associated with weight loss (4). However, dysregulation of iron homeostasis and the associated oxidative stress are linked to the development of obesity-associated metabolic disturbances, including T2DM (5), metabolic syndrome (6), central adiposity and cardiovascular disease (7). Iron has been shown to be accumulated in the liver and adipose tissues of patients and rodent models with diabetes mellitus (DM) $(5,8,9,10)$, but less is understood about the mechanisms underlying these associations. In adipose tissue, intracellular mediators of iron homeostasis, including iron uptake through divalent metal transporter (DMT1) and transferrin receptor (TFR), iron storage through transferrin and iron export through ferroportin (Fpn), contribute to changes in physiology and adipogenesis $(8,11,12)$.

However, there are still some conflicting findings concerning the impact of obesity on the adipose iron status, as some studies have determined that obesity is associated with iron deficiency and hyperglycemia despite enhanced insulin sensitivity (13). Conversely, it is well demonstrated that excess iron in adipose tissue boosts adipose tissue dysfunction, resulting in decreased adipogenesis and enhanced adipocyte inflammation and adipose tissue macrophage infiltration $(8,11,14)$. Consistently, iron overload has detrimental effects on adipocyte differentiation at the cellular level, whereas iron deprivation reverses this effect completely $(15,16)$. In humans, therapeutic phlebotomy has been shown to improve insulin resistance, diabetes and metabolic syndrome including hypertriglyceridemia, non-alcoholic steatohepatitis and obesity hypoventilation syndrome, especially in conditions associated with iron overload $(17,18,19)$. Therefore, it is conceivable that the use of iron chelators significantly delays the development of obesity (9).

Recently, our study demonstrated that desferrioxamine (DFO), a classical iron chelator, had safety- and efficacyassociated effects on hepatic steatosis and weight loss in ob/ob mice via suppression of redox damage and an increase in hypoxia-inducible factor- $1 \alpha$ (HIF- $1 \alpha)$ activity, resulting in an increase in proteins related to lipid metabolism, including peroxisome proliferator-activated receptor- $\gamma$ (PPAR $\gamma)$, PPAR $\gamma$ co-activator 1 alpha (PGC- $1 \alpha$ ) and uncoupling protein (UCP) 1 (10). Of note, adipose tissue highly expresses HIF-1 $\alpha$ due to the inability of the tissue to mount compensatory angiogenesis in obese mice and individuals $(20,21,22)$, whereas the inhibition of HIF- $1 \alpha$ in adipocytes induces glucose intolerance and severe obesity (23), suggesting that HIF-1 $\alpha$ might act as

http://www.endocrineconnections.org https://doi.org/10.1530/EC-18-0054

C 2018 The authors Published by Bioscientifica Ltd a key factor for hypoxia adaptation in adipose tissue (24). These findings prompted us to explore the precise molecular mechanism responsible for the effects of iron on lipid metabolism. In the present study, in addition to antioxidant and anti-inflammatory actions (9), we found that DFO might play a role in ameliorating the iron overload associated with obesity by increasing UCP1, PPAR $\gamma$, PGC- $1 \alpha$ and HIF- $1 \alpha$ expression and by improving insulin resistance of adipose tissue via the corresponding signaling pathways.

\section{Materials and methods}

\section{Animals and treatments}

Male ob/ob mice (aged 24 weeks, Jackson Laboratory) were randomly divided into groups: vehicle and DFO (8 mice per group). As described in previous reports, mice in the DFO group were given DFO (Sigma D9533, $100 \mathrm{mg} / \mathrm{kg}$ body weight, dissolved in saline, intraperitoneally once a day (i.p.q.d.)) for 15 days (10). Mice in the vehicle group were treated with the vehicle control. Obese mice and age-matched WT $(\mathrm{C} 56 \mathrm{BL} / 6 \mathrm{~J})$ mice were housed in a temperature-controlled $\left(22 \pm 2^{\circ} \mathrm{C}\right)$ environment on a 12 -h light/dark cycle with free access to food and water. The general health and body weights of the animals were monitored for the duration of the experiment. After the treatment, the white adipose tissues of the epididymal fat were rapidly collected with the animals under anesthesia, and bisected halves were fixed in $4 \%$ paraformaldehyde in phosphate-buffered saline or snap-frozen in liquid nitrogen and stored at $-80^{\circ} \mathrm{C}$ for future assessment. Experimental procedures were performed in accordance with the National Institutes of Health guidelines and were approved by the Laboratory Animal Ethical Committee of Northeastern University.

\section{Histological evaluation}

Samples from the epididymal fat pads of all mice were routinely fixed in $4 \%$ paraformaldehyde for at least $24 \mathrm{~h}$, embedded in paraffin and cut into $6-\mu \mathrm{m}$ sections according to a standard protocol. Then, the fat pad sections were stained with hematoxylin and eosin (H\&E). The sectional areas of the epididymal fat pads of each animal were then evaluated to quantify the sizes of the fat droplets using a light microscope equipped with a digital camera (DM4000B, Leica). 
Immunohistochemistry, immunofluorescence and iron histochemistry with Perl's staining

To detect iron accumulation in the epididymal fat tissue, 3,3'-diaminobenzidine tetrahydrochloride (DAB)-enhanced Perl's staining was implemented as previously described (25). Briefly, 6- $\mu \mathrm{m}$ sections were routinely dewaxed, rehydrated and treated in $0.1 \mathrm{M}$ Tris-buffer saline (TBS, pH 7.4) containing 3\% hydrogen peroxide $\left(\mathrm{H}_{2} \mathrm{O}_{2}\right)$ for $10 \mathrm{~min}$, and the sections were then immersed in Perl's solution containing equal parts of freshly prepared aqueous potassium ferrocyanide (2\%) and hydrochloric acid (2\%) for $30 \mathrm{~min}$. For immunohistochemistry, the antigens of the rehydrated adipose or liver tissue sections were repaired by microwave in citric acid buffer for $3 \mathrm{~min}$. The sections were then washed, treated with $5 \%$ bovine serum albumin for $30 \mathrm{~min}$ and subsequently incubated overnight with rabbit antiHepcidin (1:100; Santa Cruz Biotechnology) at $4^{\circ} \mathrm{C}$. The sections were rinsed and then incubated with biotinylated goat anti-rabbit IgG (1:200) for one hour, followed by streptavidin peroxidase incubation for one hour at room temperature. Afterward, the sections were rinsed and finally intensified with $0.025 \%$ DAB plus $0.0033 \%$ $\mathrm{H}_{2} \mathrm{O}_{2}$ in TBS for $10 \mathrm{~min}$. After washing, the slides were dehydrated, cleared, covered and measured under a light microscope equipped with a digital camera (DM4000B, Leica). For immunofluorescence, sections of adipose tissue were treated with rabbit anti-TFAM (Mitochondrial Transcription Factor A, 1:50; Bioss, Beijing, China), DAPI and MitoTracker Green (KGMP007, KeyGen Biotech, Nanjing, China). Images were captured on a fluorescence microscope (Leica, SP8). The control sections were treated with identical solutions but without the primary antibody and were processed as described earlier.

\section{Transcript quantification}

Quantitative RT-PCR was performed as described previously (10). Briefly, mRNA was extracted from the epididymal adipose tissues using TRIzol (Invitrogen), and synthesized into cDNA using the Prime Script TM RT Reagent Kit (Takara). Quantitative PCR assays were performed with the SYBR Green PCR Master mix (Promega) using a MiniOpticon Real-Time PCR detection system (Bio-Rad), and the values were normalized to GAPDH. The following PCR primers were used for quantification: TNF $\alpha$ : forward, AGCCCCCAGTCTGTATCCTT and reverse, ACAGTCCAGGTCACTGTCCC; IL-1 $\beta$ : forward, TTCAAATCTCGCAGCAGCAC and reverse,
GTGCAGTTGTCTAATGGGAACG; IL-2: forward, GCCCA AGCAGGCCACAGAAT and reverse, GGGCTTGTTGAGAT GATGCTTTGA; IL-6: forward, TGTCTATACCACTTCACAA GTCGGAG and reverse, GCACAACTCTTTTCTCAT TTCCAC; Hepcidin: forward, TGCCTGTCTCCTG CTTCTCCTCC and reverse, TCGCAATGTCTGCCCTG CTTTC; and GAPDH: forward, GGATTTGGTCGTATTGGG and reverse, TCGCTCCTGGAAGATGG.

\section{Measurement of ROS}

To determine whether DFO treatment decreased oxidative stress in adipose tissues, reactive oxygen species (ROS) production was measured using $2^{\prime}, 7^{\prime}$-dichlorofluorescein diacetate (DCFH-DA) according to the manufacturer's protocol (E004, Jiancheng Biology, Nanjing, China). The DCF fluorescence intensity was measured at the $485 \mathrm{~nm}$ excitation and $525 \mathrm{~nm}$ emission wavelengths using a microplate reader (Synergy/H1, BioTek).

\section{Western blot analyses}

Samples from the adipose tissues were lysed in an icecold lysis buffer containing a protease inhibitor cocktail (Sigma-Aldrich), and the obtained protein concentrations were determined using the bicinchoninic acid (BCA) protein assay reagent (Pierce Biotechnology). Proteins (30 mg) were subjected to SDS-PAGE, transferred onto polyvinylidene difluoride (PVDF) membranes (Millipore), and incubated overnight at $4^{\circ} \mathrm{C}$ with a panel of specific antibodies. Primary antibodies against rabbit anti-DMT1 (1:3000, Alpha Diagnostic, Paramus, NJ, USA), rabbit antiGlycogen Synthase Kinase $3 \alpha / \beta(\mathrm{GSK} 3 \alpha / \beta, 1: 1000$, Cell Signaling Tech (CST)), rabbit anti-p-GSK3 $\alpha / \beta$ (1:1000, CST), rabbit anti-HIF-1 $\alpha$ (1:1000, Novus, Littleton, CO, USA), rabbit anti-insulin receptor (IR, 1:1000, CST), rabbit anti-p-IR (1:1000, CST), rabbit anti-c-Jun N-terminal kinase (JNK1/2, 1:1000, CST), rabbit anti-p-JNK1/2 (1:1000, CST), rabbit anti-NF-кB p65 (1:1000, CST), rabbit anti-P38 (1:1000, CST), rabbit anti-p-P38 (1:1000, CST), rabbit anti-PGC-1 $\alpha$ (1:1000; CST), rabbit anti-PPAR $\gamma$ (1:1000; CST), mouse anti-SLC40A (Fpn, 1:1000, Abcam), mouse anti-transferrin receptor (TFR, 1:1000, Invitrogen) and rabbit anti-UCP-1 (1:3000; R\&D) were used to probe the membrane. $\beta$-Actin $(1: 10,000$, Sigma) was used as a normalizing control. After washing, the membranes were incubated with horseradish peroxidase (HRP)-labeled secondary antibodies (1:5000; Santa Cruz Biotechnology) for $1 \mathrm{~h}$. Blots were visualized using ECL Kits (Pierce Biotechnology) and ChemiDoc XRS with Quantity One http://www.endocrineconnections.org https://doi.org/10.1530/EC-18-0054
(C) 2018 The authors Published by Bioscientifica Ltd
This work is licensed under a Creative Commons Attribution-NonCommercial 4.0 International License. 
software (Bio-Rad). The band intensities were quantified using ImagePro Plus 6.0 analysis software.

\section{Statistical analyses}

All assays were performed at least in triplicate, and the values are expressed as the mean \pm standard deviation (s.D.). Differences between the means of two groups were compared using an unpaired two-tailed Student's $t$-test. Statistical significance was considered at $P<0.05$.

\section{Results}

\section{Effects of obesity on iron status and metabolism of adipose tissue}

In light of studies that have suggested pivotal roles for the adipose iron status in obesity $(5,8)$, we first evaluated the concentrations of iron in adipose tissues from genetically 26-week-old obese (C57BL/6J, ob/ob) mice and age-matched WT C57BL/6J mice. As shown in Fig. 1A, DAB-enhanced Perl's staining analysis revealed that iron deposits were statistically increased in the epididymal fat pad of adult ob/ob mice compared with WT mice. As expected, the expression levels of UCP1 and PPAR $\gamma$ were markedly decreased in the adipose tissues of ob/ob mice (Fig. $1 \mathrm{~B}, \mathrm{C}$ and $\mathrm{D}, \mathrm{P}<0.05)$. In addition, the expression levels of DMT1 and TFR were obviously decreased (Fig. 1B, $\mathrm{E}$ and $\mathrm{F}, \mathrm{P}<0.05)$ in the adipose tissues of ob/ob mice. However, there was no statistical difference in the Fpn level in the adipose tissues although there was a trend toward an increase in the ob/ob mice compared with the WT mice (Fig. 1B and G, P>0.05). These observations further reinforced the potential involvement of iron in obesity.

\section{DFO treatment ameliorates lipid metabolism in adipose tissues of ob/ob mice}

We previously showed that body weight tended to be decreased, whereas body temperature was significantly elevated after DFO treatment, indicating that the DFO-induced reduction in body weight might be involved in energy dissipation in ob/ob mice (10). In this study, we first assessed the effects of DFO on adipose tissue pathology. As shown in Fig. 2A, the smaller adipocytes in the epididymal fat pad was more frequency in the DFO-treated ob/ob mice than that in the vehicle-treated ob/ob mice, indicating decreased fatty accumulation in the adipose tissues of the ob/ob mice.

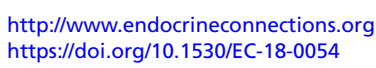

To further evaluate the effect of DFO treatment on activation of adipogenesis and thermogenesis, we measured the expression levels of UCP1, PPAR $\gamma$ and PGC- $1 \alpha$ in the epididymal adipose tissues of mice. Western blot analysis revealed that the expression levels of UCP1, PPAR $\gamma$ and PGC- $1 \alpha$ in the DFO-treated mice were higher than those of the vehicle-treated mice (Fig. 2B, C, D and E, $P<0.05)$. Interestingly, we found that DFO treatment significantly increased the expression level of TFAM in the adipose tissue of ob/ob mice (Fig. $2 \mathrm{~F}, P<0.05$ ). Immunofluorescence results using co-immunolabeling of TFAM and MitoTracker Green indicated that mitochondrial content was enhanced with increased levels of TFAM in the adipose tissue from the DFO-treated mice relative to vehicle controls (Fig. 2G).

These findings indicate that DFO treatment could substantially ameliorate adipocyte hypertrophy by mediating the lipid metabolism and mitochondrial biogenesis of the adipose tissue in ob/ob mice.

\section{DFO treatment improves insulin sensitivity in the adipose tissues of ob/ob mice}

It is well known that the impacts of iron overload on adipose tissue are associated with insulin resistance (11). Moreover, we previously found that serum insulin level in the $o b / o b$ mice decreased significantly after DFO treatment (10). To explore the possibility that direct chelation of DFO in adipose tissue is responsible for antiobesity and improved insulin sensitivity, components of the insulin signaling pathways were investigated in adipose tissue. Western blot analysis demonstrated that, compared with the vehicle-treated $o b / o b$ mice, the DFO treatment significantly increased the levels of p-IR, p-AKT and p-GSK $3 \alpha / \beta$, but there were no significant differences in the total amounts of IR, AKT and GSK3 $\alpha / \beta$ (Fig. 3A, B, $\mathrm{C}$ and $\mathrm{D}, P<0.05)$.

\section{DFO treatment improves iron accumulation and regulates intracellular iron metabolism in the adipose tissues of ob/ob mice}

We then investigated whether amelioration of adipocyte hypertrophy by DFO was involved in the distribution and metabolism of iron in the epididymal adipose tissues of ob/ob mice. Analysis of the Perl's DAB-stained sections confirmed that iron-positive cells were distributed throughout the adipose tissues in all examined animals (Fig. 4A). Iron deposits were mainly located as brown granules in the adipocytic cytoplasm around the

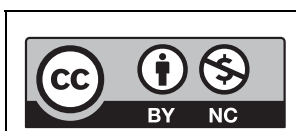

This work is licensed under a Creative Commons Attribution-NonCommercial 4.0 International License. 
A
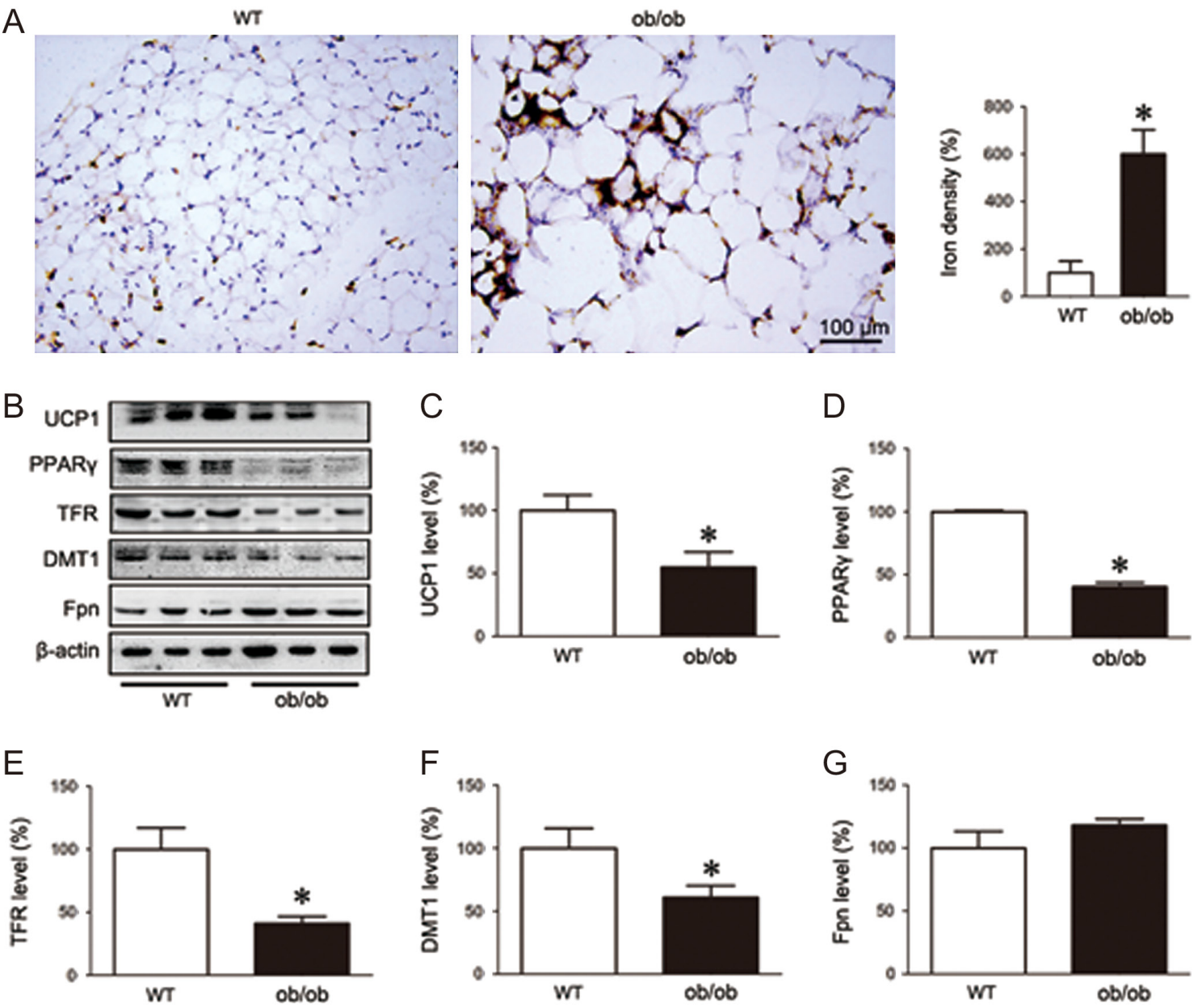

Figure 1

Effects of obesity on iron status and metabolism of adipose tissue. (A) Perl's DAB staining confirmed that iron deposits were statistically increased in the epididymal fat pad of adult ob/ob mice compared with WT mice. (B, C, D, E, F and G) Western blot analysis revealed that the levels of UCP1, PPAR DMT1 and TFR were significantly decreased in the adipose tissues of the ob/ob mice, compared with the WT mice. $\beta$-Actin was the internal control. The data are presented as the mean \pm s.D. $(n=8)$. ${ }^{*} P<0.05$ compared with the vehicle control.

marginal nucleus and the interstitial spaces. However, the iron-positive staining density (especially outside the adipocytes) in the adipose tissues of the DFO-treated mice was relatively lower than that in those of the vehicletreated mice (Fig. 4A, $P<0.05$ ), indicating a decreased iron concentration in the adipose tissues of DFO-treated mice.

Next, we further analyzed the effects of DFO on the expression levels of several major iron transport-related proteins, namely, TFR, DMT1 and Fpn, in adipose tissue. TFR expression at the protein level was significantly increased in the adipose tissues (Fig. $4 \mathrm{~B}$ and $\mathrm{D}, P<0.05$ ), but there was no significant difference in the expression levels of DMT1 after the DFO treatment compared with the vehicle control (Fig. 4B and E, $P>0.05$ ). Meanwhile, we also observed that treatment with DFO promoted a significant reduction in Fpn expression in the adipose tissues of the $o b / o b$ mice (Fig. $4 \mathrm{~B}$ and C, $P<0.05$ ), suggesting

\begin{tabular}{lr}
\hline http://www.endocrineconnections.org & ○ 2018 The authors \\
https://doi.org/10.1530/EC-18-0054 & Published by Bioscientifica Ltd
\end{tabular}

that the DFO treatment resulted in an increase in iron uptake and a decrease in iron export for the maintenance of adipocytic iron homeostasis.

\section{DFO treatment abates inflammation by controlling oxidative stress, NF-кB p65 and JNK activation in the adipose tissues of ob/ob mice}

To assess how DFO treatment affects the development of adipose tissue inflammation, we first investigated the expression levels of SOD1, Gpx4 and NF-kB p65 and activation of JNK. As shown in Fig. 5, compared with the vehicle-treated controls, the SOD and Gpx4 protein levels were markedly increased in the animals treated with DFO for 15 days (Fig. 5A, C and D, $P<0.05$ ), whereas ROS production was significantly decreased (Fig. 5B, $P<0.05)$. Moreover, compared with the vehicle-treated

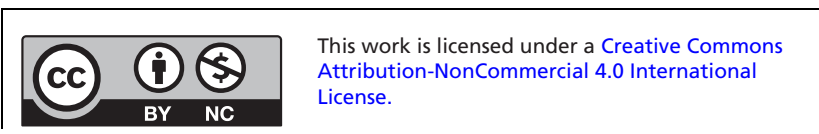


A
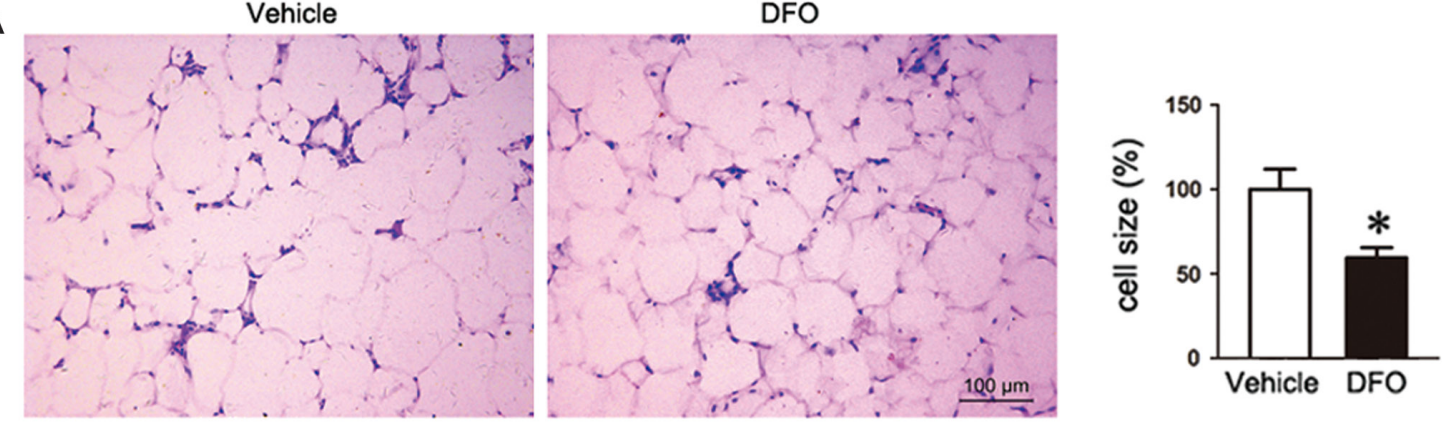

B

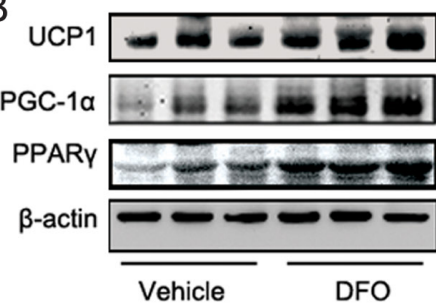

C

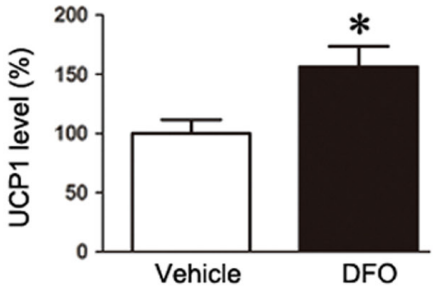

D

E

F
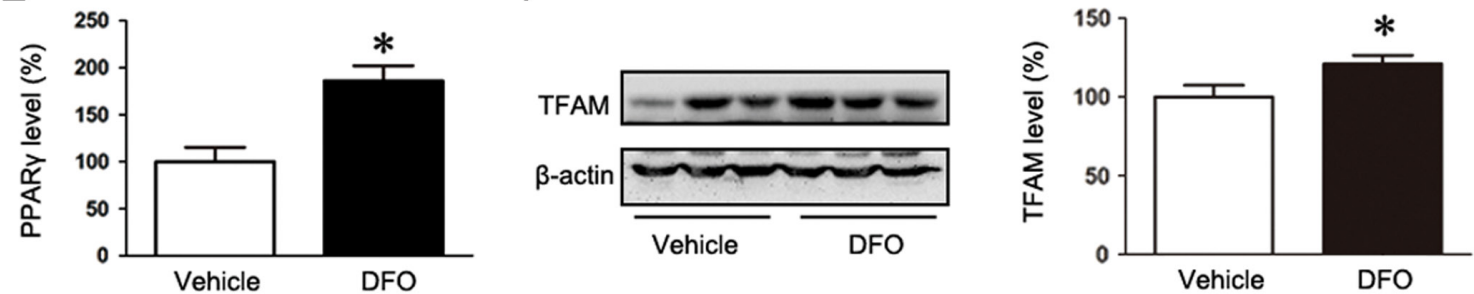

G
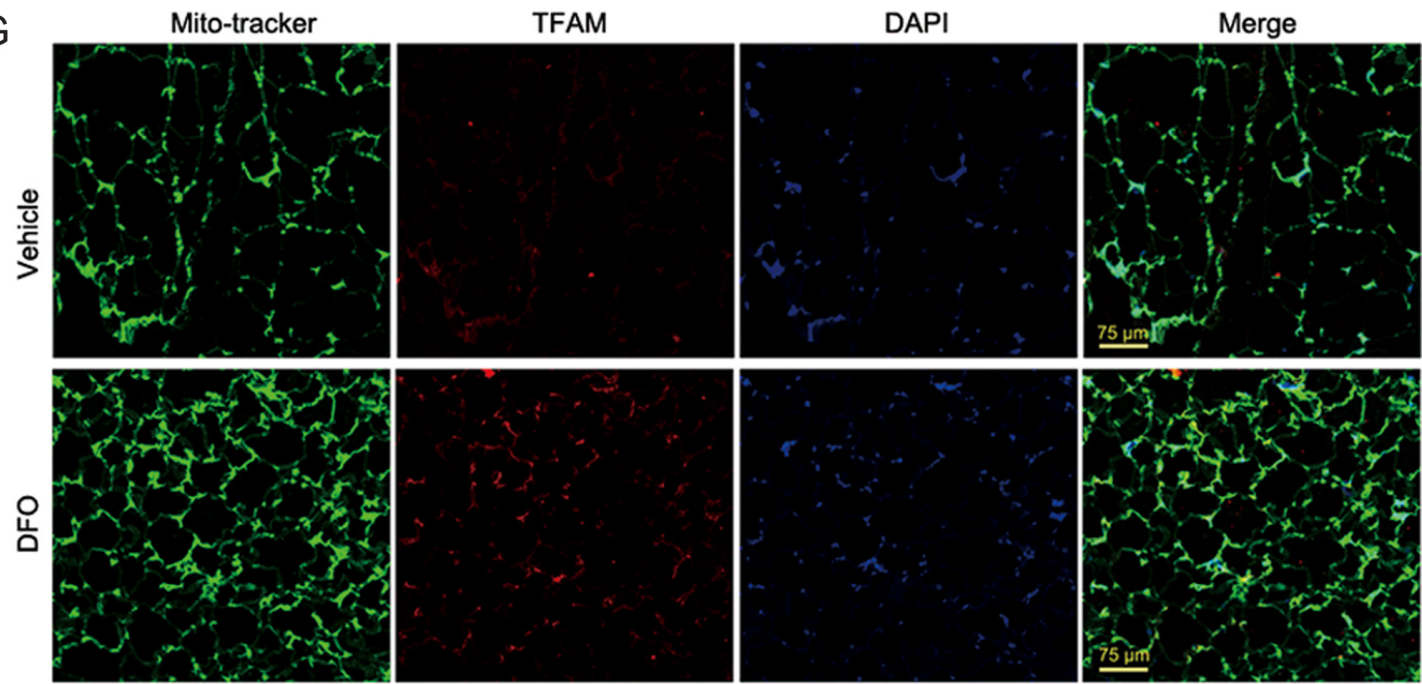

Figure 2

DFO treatment ameliorates adipose tissue pathology and lipid metabolism in ob/ob mice. (A) Histopathological examination by H\&E staining showed that the DFO treatment altered adipocyte size in the ob/ob mice at 26 weeks. (B, C, D, E and F) Western blot analysis revealed that the expression levels of UCP1, PPAR $\gamma$, PGC- $1 \alpha$ and TFAM were higher in the DFO-treated mice than in the vehicle-treated mice. $\beta$-Actin was the internal control. (G) Immunofluorescence with Anti-TFAM antibody, DAPI and MitoTracker Green in the adipose tissues. The data are presented as the mean \pm S.D. ( $n=8$ ) $* P<0.05$ compared with the vehicle control.

\begin{tabular}{lr}
\hline http://www.endocrineconnections.org & ○ 2018 The authors \\
https://doi.org/10.1530/EC-18-0054 & Published by Bioscientifica Ltd
\end{tabular}



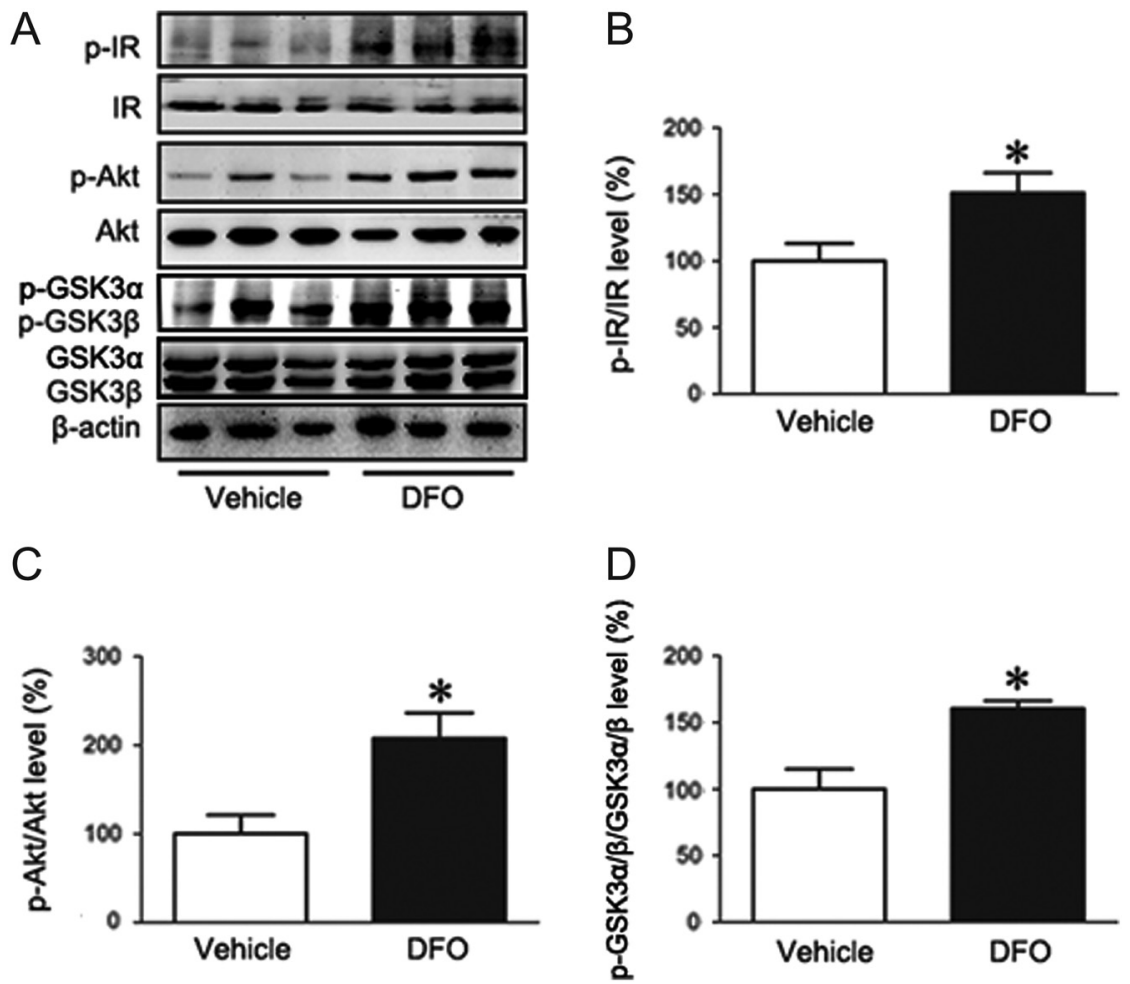

\begin{abstract}
Figure 3
Effects of DFO on insulin resistance in the adipose tissues of ob/ob mice. (A, B, C and D) The levels of proteins associated with the insulin signaling pathway were evaluated by Western blotting. (B, $C$ and D) Statistical analysis showed that the DFO treatment significantly increased the $p-I R / I R$, p-AKT/AKT and p-GSK3 $\alpha / \beta / G S K 3 \alpha / \beta$ ratios. $\beta$-Actin was the internal control. The data are presented as the mean \pm s.D. $(n=8) .{ }^{*} P<0.05$ vs vehicle control.
\end{abstract}

mice, the DFO treatment significantly decreased the levels of NF- $\kappa \mathrm{B}$ and activated p-JNK (Fig. 5A, E and G, $P<0.05$ ). Consequently, the DFO-induced antioxidant effects decreased the mRNA levels of inflammatory cytokines such as TNF $\alpha, I L-2$ and IL-6 (Fig. 5I, J and $\mathrm{K}, P<0.05$ ), although the level of $I L-1 \beta$ mRNA showed an increasing trend in the DFO-treated mice compared with the vehicle-treated ob/ob mice. Of note, immunohistochemistry analysis of the sections confirmed that Hepcidin was highly expressed in both the liver cells and adipocytes of the untreated ob/ob mice and that the DFO treatment weakened the positive signals, although the level of Hepcidin mRNA did not significantly change in the liver, even markedly increased in adipose tissue of DFO-treated mice (Fig. 5L and $\mathrm{M}$ ). However, the level of the cleaved caspase- 3 protein did not show a statistically significant decrease in the DFO-treated mice (Fig. 5A and F, $P>0.05$ ). These findings indicate that DFO treatment can substantially inhibit adipose tissue inflammation without affecting apoptosis in ob/ob mice.

\title{
DFO treatment induces increased HIF-1 $\alpha$, GLUT1 and GLUT4 expression by activation of P38 in the adipose tissues of ob/ob mice
}

Our previous study revealed that DFO could induce HIF-1 $\alpha$ accumulation via P38 MAPK-dependent mechanisms in fatty degeneration of the mouse liver

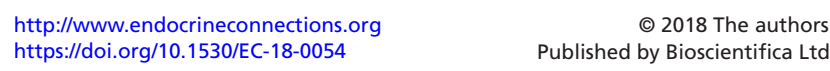

(10). Thus, experiments were also performed to determine whether DFO treatment could affect the expression of HIF-1 $\alpha$ and HIF-1-adaptive targets. Indeed, at the end of 15 days of DFO treatment, phosphorylation of P38 was significantly increased in parallel with increased protein levels of HIF-1 $\alpha$, GLUT1 and GLUT4 in the adipose tissues of the ob/ob mice (Fig. 6A, B, C, D and E, $P<0.05$ ). These results suggest that the P38/HIF-1 $\alpha$ pathway is involved, in part, in the improvement of adipocytic glucose homeostasis and insulin resistance in ob/ob mice.

\section{Discussion}

We have shown that DFO treatment alleviates hepatic steatosis via reductions in hepatic iron deposition, oxidative stress and proinflammatory cytokines and via increases in HIF- $1 \alpha$ and lipid- and energy-associated metabolism proteins in ob/ob mice (10). In line with this idea, we also found that the reduction in iron levels by iron chelator DFO can ameliorate adipocyte hypertrophy by suppressing oxidative stress and inflammatory cytokines as reported previously in obese and type 2 diabetes KKAy mice (9). More importantly, we have demonstrated that DFO directly targets several key regulators of HIF-1 $\alpha$ and its target proteins (GLUT1 and GLUT4), adipogenesis

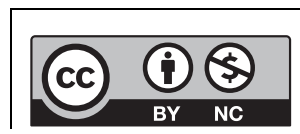

This work is licensed under a Creative Commons Attribution-NonCommercial 4.0 International License. 

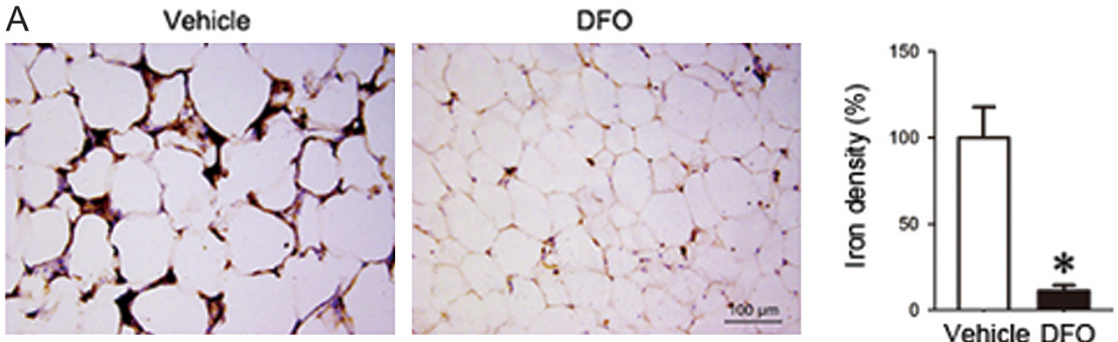

B
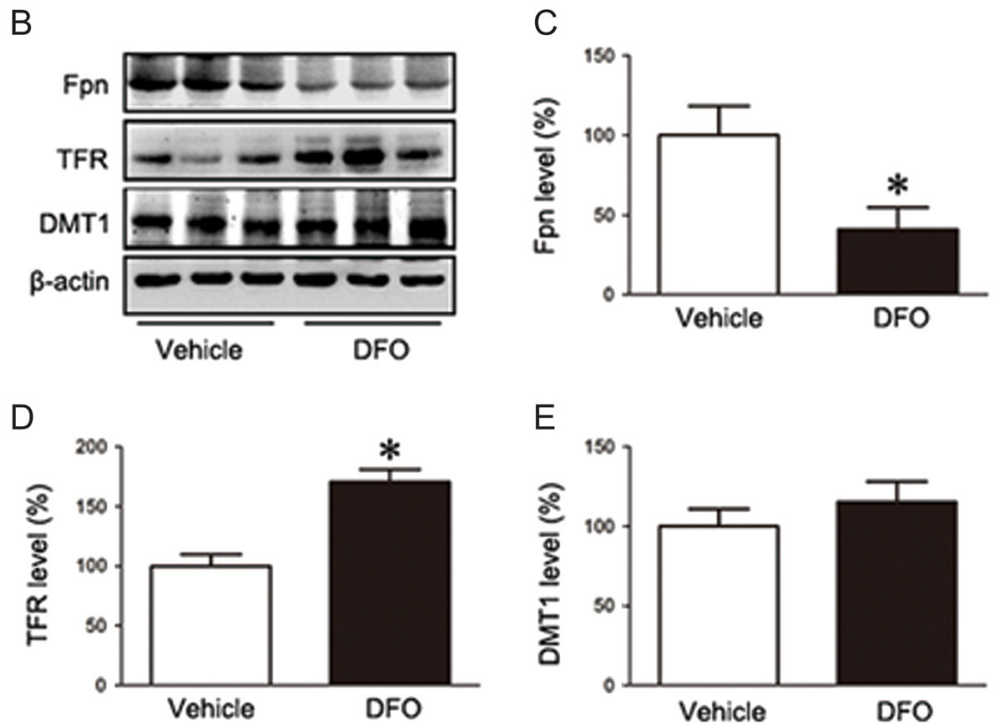

\begin{abstract}
Figure 4
DFO treatment improves iron accumulation and regulates intracellular iron metabolism in the adipose tissues of ob/ob mice. (A) Perl's DAB staining confirmed that the DFO treatment improved adipose tissue iron deposition in the ob/ob mice. (B, C, D and E) Western blot analysis revealed that the levels of TFR were significantly increased and that Fpn expression was decreased in the adipose tissues of the ob/ob mice. $\beta$-Actin was the internal control. The data are presented as the mean \pm S.D. $(n=8) .{ }^{*} P<0.05$ compared with the vehicle control.
\end{abstract}

and thermogenesis (UCP1, PPAR $\gamma$, PGC- $1 \alpha$, and TFAM), adipocytic iron homeostasis (TFR, DMT1, Fpn, and Hepcidin), and insulin signaling.

Many studies have also reported that ob/ob mice have shown obesity and histopathological characteristics such as enlarged fat $(26,27)$; however, the interaction between the abnormal iron homeostasis and the progression of histopathological changes of adipose tissues has not been elucidated. In agreement with previous observations with older ob/ob mice $(28,29)$, we confirmed that fat iron concentrations were significantly elevated relative to agematched WT mice. Accordingly, we also found that various markers of lipid metabolism, such as UCP1 and PPAR $\gamma$, were significantly down-regulated, and iron-uptakerelated proteins TFR and DMT1 were all concomitantly down-regulated, but the only iron output protein Fpn was slightly up-regulated in ob/ob mice compared to WT mice. Our data indicate that iron deposition is increased in adipose tissues of 26-week-old ob/ob mice along with accumulated fat, which likely results in the compensatory response via changed iron regulation proteins expression. Thus, it is tempting to speculate that strategies to reduce iron concentration might ameliorate adipocyte dysfunction.

$$
\text { http://www.endocrineconnections.org }
$$

In fact, during the present study, we compared mice that received intraperitoneal DFO to those that received vehicle alone and found that the body weights of the ob/ ob mice tended to be decreased after the DFO treatment, whereas no significant difference in food intake and the ratio of the liver weight to body weight between the groups was evident, indicating that the DFO-induced reduction in body weight might be involved in energy dissipation in ob/ob mice (10). This finding led us to investigate obesityrelated pathologies in the adipose tissues of DFO- and vehicle-treated ob/ob mice. Here, histological examination of the adipose tissues revealed that the DFO treatment decreased adipocyte hypertrophy compared with vehicle alone in the ob/ob mice. To determine the mechanism underlying these histological differences, we examined the adipose tissue proteins associated with dysfunctional adipocyte lipid mechanism $(30,31)$. We found that the UCP1, PPAR $\gamma$ and PGC-1 $\alpha$ levels were significantly higher in the DFO-treated mice. It should be noted that DFO treatment improved PGC- $1 \alpha$ induced TFAM expression and mitochondrial content, suggesting that mitochondrial biogenesis, which plays an important role in cell survival and repair (32), was increased in adipose tissue of ob/ob mice. Interestingly, the over-expressed PGC- $1 \alpha$ in white

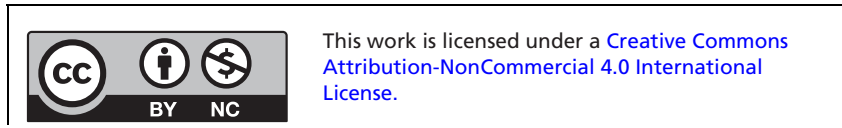


A

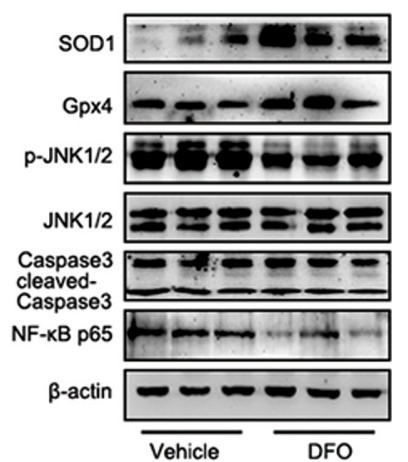

$\mathrm{H}$

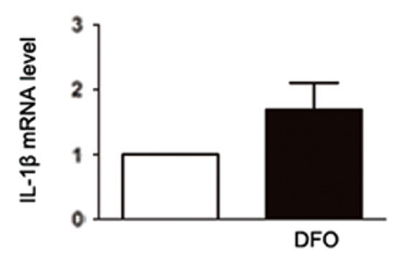

B
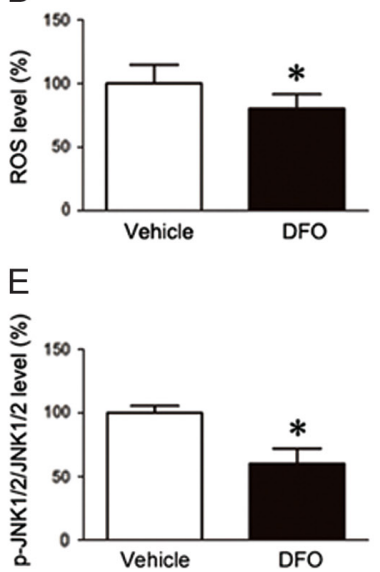

I

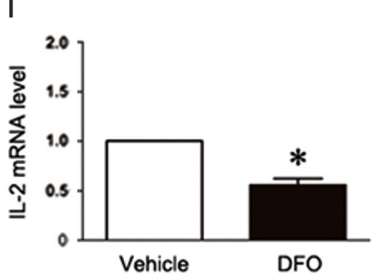

C

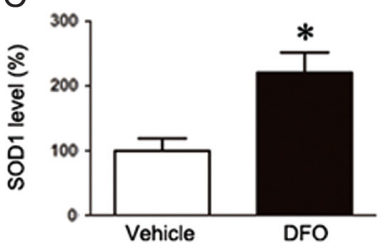

$\mathrm{F}$

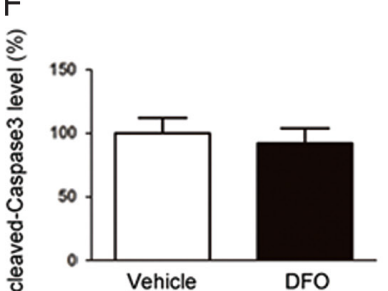

$\mathrm{J}$
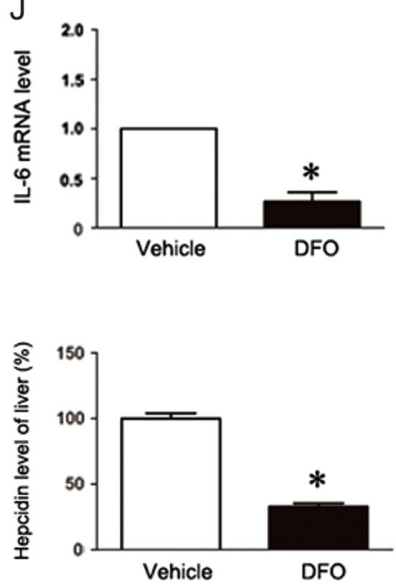

DFO

M

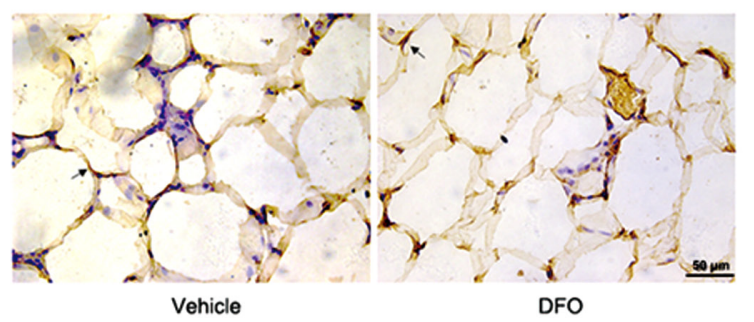

L

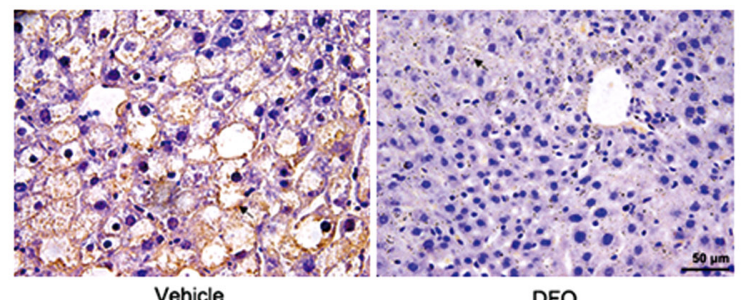

Vehicle

Vehicle

DFO

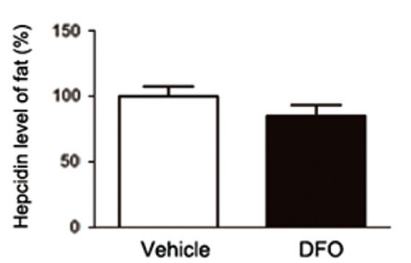

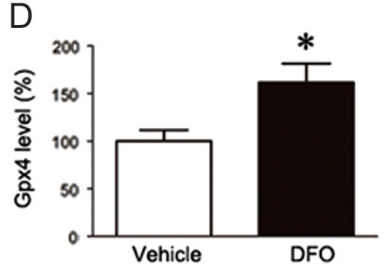

G
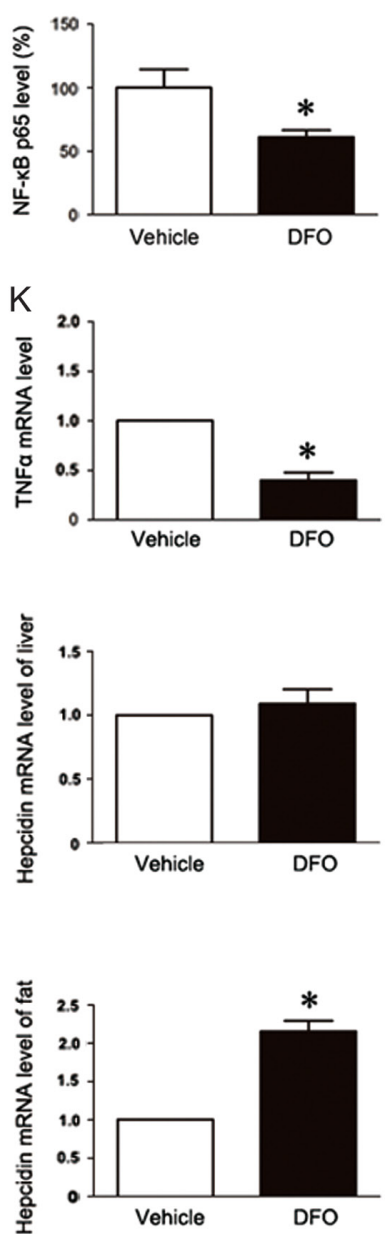

Figure 5

Effects of DFO on the adipose tissue oxidative stress and inflammatory signaling pathways of ob/ob mice. (A) The fat samples were lysed, and Western blotting was performed. $\beta$-Actin was the loading control. The figure shows representative results obtained in 8 mice per group. (B) DFO treatment lowered the ROS contents of the adipose tissues in the ob/ob mice. (C, D, E, F and G) As assessed by Western blot, the SOD1 and Gpx4 protein levels were increased, and the $\mathrm{p}-\mathrm{JNK} 1 / 2 / \mathrm{JNK} 1 / 2$ ratio and NF-кB p65 level were decreased; however, there was no significant difference in the expression level of cleaved-caspase-3 after the DFO treatment. ( $\mathrm{H}, \mathrm{I}, \mathrm{J}$ and $\mathrm{K}$ ) Total RNA was extracted from the same fat samples in the ob/ob mice, and the $I L-1 \beta, I L-2, I L-6$ and TNF- $\alpha$ mRNA levels were quantified relative to the GAPDH mRNA levels. (M and L) Representative data of the immunohistochemical staining analysis with the Hepcidin antibody (black arrows) in paraffin-embedded sections of the liver and epididymal fat from the ob/ob mice, and the mRNA levels of Hepcidin were also quantified. The data are presented as the mean \pm s.D. $(n=8)$. ${ }^{*} P<0.05$ compared with the vehicle control.

adipocytes may lead to a phenotype similar to that of brown adipose tissue (33). Of course, we will need further study to clarify them. Together with the findings of our previous study, in which DFO was shown to decrease serum lipids and increase body temperature (10), the findings of the present study suggest that treatment with iron chelators might improve adipogenesis and thermogenesis in adipose tissues of ob/ob mice.

It has been demonstrated that ob/ob mice are predisposed to the development of obesity, insulin http://www.endocrineconnections.org https://doi.org/10.1530/EC-18-0054 (c) 2018 The authors Published by Bioscientifica Ltd

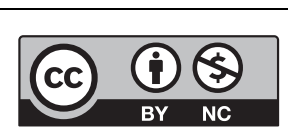

This work is licensed under a Creative Commons Attribution-NonCommercial 4.0 International License. 
A

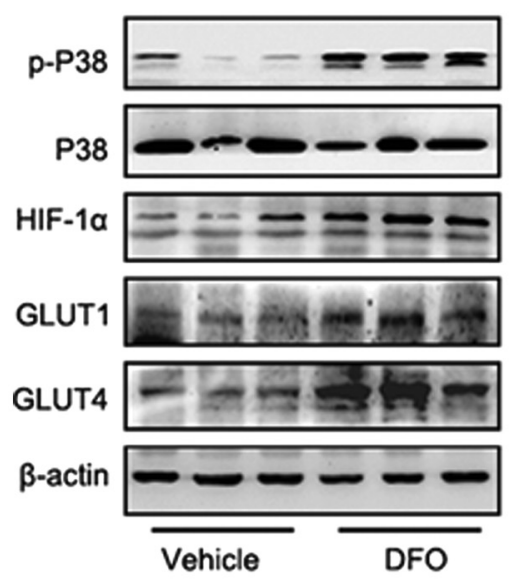

D

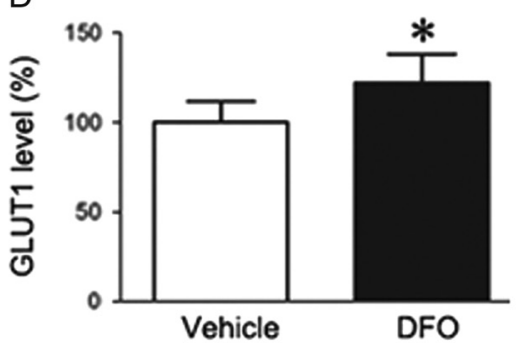

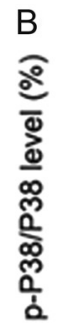
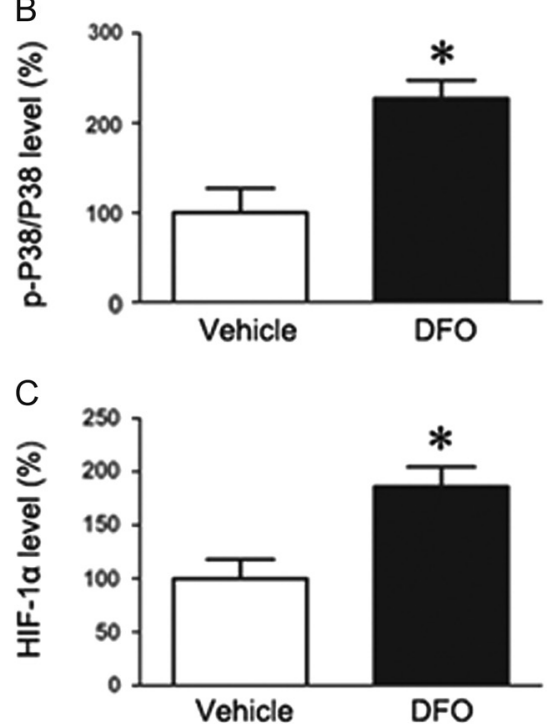

E

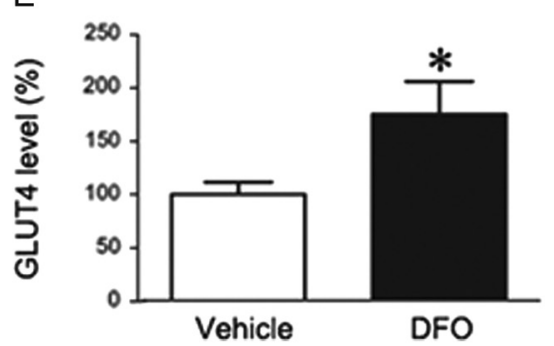

Figure 6

DFO treatment induces increased HIF- $1 \alpha$, GLUT1 and GLUT4 expression via activation of P38MAPK in the adipose tissues of ob/ob mice. (A) Total protein was extracted from the same fat samples. The protein levels of p-P38, P38, HIF- $1 \alpha$, GLUT1 and GLUT4 were determined by Western blotting and normalized to the $\beta$-actin protein levels. Statistical analysis showed that the DFO treatment significantly increased the p-P38/P38 ratio and (B) the protein levels of HIF-1 $\alpha(C)$, GLUT1 (D), and GLUT4 (E) in the adipose tissues of the ob/ob mice. The data are presented as the mean \pm s.D. $(n=8) .{ }^{*} P<0.05$ compared with the vehicle control. resistance and dyslipidemia (34). Furthermore, it is noteworthy that iron is associated with adipocyte insulin resistance and T2DM $(35,36)$. It has been reported that, in murine models, iron-enriched diets decrease adipocyte insulin sensitivity and are associated with visceral adipose tissue hyperplasia and hypertrophy; however, ironrestricted diets lead to opposite effects $(16,37)$. Therefore, we presume that the DFO-induced decrease in adipocyte hypertrophy may also be related to increased insulin sensitivity and a subsequent reduction in adipogenesis and visceral adiposity $(14,38)$. Here, we observed significant increases in the phosphorylated levels of IR, AKT and GSK3 $\beta$ in the adipose tissues of DFO-treated ob/ob mice compared with vehicle-treated ob/ob mice, which was the expected result.

In fact, growing evidence supports the involvement and interrelatedness of iron and adipocyte metabolism $(14,35,39,40)$. To clarify the mechanisms of the abovementioned effects by iron chelators, we further assessed whether the DFO treatment modulated iron distribution and metabolism in the adipose tissues of the $\mathrm{ob} / \mathrm{ob}$ mice. We found that the histological features of iron accumulation in the adipose tissue were markedly improved after 15 days of DFO treatment. Concerning

$$
\begin{aligned}
& \text { http://www.endocrineconnections.org } \\
& \begin{array}{l}
\text { https://doi.org/10.1530/EC-18-0054 } 2018 \text { The authors } \\
\text { Published by Bioscientifica Ltd }
\end{array}
\end{aligned}
$$

the involvement of various iron transport proteins in the protective effect of DFO against iron-deposition obesity-related pathologies, we demonstrated that TFR, an iron uptake protein, was increased, while Fpn, the only iron-export-related protein, was reduced. Intriguingly, compared to the vehicle-treated ob/ob mice, weak Hepcidin staining by immunocytochemical analysis was detected in both the hepatocytes and adipocytes obtained from the DFO-treated ob/ob mice, but the level of Hepcidin mRNA did not significantly change in the liver, even markedly increased in adipose tissue. It is possible that the increased Hepcidin mRNA levels in the adipocytes may be exploited to down-regulate FPN expression, thereby contributing to iron homeostasis within these cells after DFO treatment. Indeed, recent studies have also noted that Hepcidin, an adipokine synthesized mainly by hepatocytes and to a minor extent by adipocytes and macrophages, is not only up-regulated by iron overload but also induced in inflammation (41), and Hepcidin expression is markedly elevated in enlarged adipose tissues $(42,43)$. It is well established that Hepcidin binds to the cellular iron exporter Fpn, resulting in the internalization and degradation of Fpn and the prevention of iron efflux from adipocytes and macrophages, thus dropping

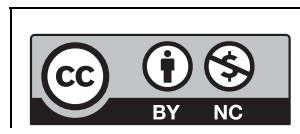

This work is licensed under a Creative Commons Attribution-NonCommercial 4.0 International License. 
systemic iron levels $(35,44)$. These findings suggest that DFO treatment reduces adipocytic iron deposition by regulating adipocyte iron homeostasis rather than by directly depriving the system of iron.

Notably, Hepcidin is not only induced by iron but also up-regulated in inflammation, largely through IL-6 (41). Iron homeostatic pathways are tightly related to inflammatory stressors, and one of the mechanisms could be through the ability of Hepcidin to cause oxidant stress that may be linked to inflammation. Thus, the expression level of Hepcidin could reflect either the availability of iron or the inflammatory state of the adipose tissue. Consistent with a previous study (9), in the present study, we showed that DFO therapy was beneficial for reducing the levels of oxidative stress and inflammatory cytokines (TNF $\alpha$, IL-2, and IL-6) in adipose tissue and for ameliorating adipocyte hypertrophy in obese ob/ob mice. Similarly, we observed increases in the activities of innate antioxidant enzymes such as Gpx4 and SOD1 in DFO-treated adipose tissue. In addition, ROS and its target JNK and NFkBp65 signaling were inhibited, but the levels of cleaved caspase- 3 were not markedly decreased after DFO treatment. Thus, the DFO-mediated improvement in visceral fat pad function can also account for the down-regulation of ROS-induced insulin resistance and inflammation $(45,46)$ rather than apoptosis.

As further evidence supporting the use of iron chelators as a potential therapeutic strategy, groups including our own have shown that iron chelators affect the stabilization of HIF- $1 \alpha$ and the activation of HIF- $1 \alpha$ target factors (10) well beyond the scope of preventing oxidant stress and inflammation (9). In fact, HIFs have also been known to regulate energy utilization in the liver, muscle and fat by stimulating glycolysis and glucose transport to increase glycolytic metabolism $(35,47)$. Nevertheless, paradoxical effects have been observed in adipocyte-specific HIF1 $\alpha$ knockout mice, where inhibition of HIF1 ameliorates obesity and insulin resistance in adipose tissue (48). Our present study demonstrated that the expression levels of HIF1 $\alpha$ and its target proteins GLUT1 and GLUT4, which are involved in glucose metabolism, were significantly elevated in the epididymal adipose tissues of the DFOtreated mice. To better understand the mechanisms of DFO-associated HIF1 $\alpha$ up-regulation, we analyzed phosphorylation of P38 and observed an increase in P38 activation in the epididymal adipose tissues of the DFOtreated mice. Accordingly, we presume that the visceral adiposity-suppressing effects of DFO may be linked to the increases in HIF $1 \alpha$ and its adaptive property-related proteins, namely TFR1 and GLUT1, in the epididymal adipose tissues of mice. Interestingly, as described earlier, activated AKT can stimulate the expression of HIF-1 $\alpha$ pathway proteins (49). Studies by several groups have demonstrated that, in skeletal muscle and white adipose tissue, PPAR $\gamma$ and PGC- $1 \alpha$ are required for induction of HIF1 $\alpha$ target proteins through a mechanism involving stabilization of $\operatorname{HIF} 1 \alpha(50,51,52)$. This observation can explain the findings of the present study whereby adipocyte dysfunction and insulin resistance in adipose tissue are improved in DFO-treated mice compared with vehicle-treated mice.

According to the current findings, iron seems to accumulate in the adipose tissues of 26-week-old ob/ob mice with increased body fat and impaired insulin actions. In addition to suppression of oxidative stress, macrophage infiltration and inflammatory cytokines (9), the alleviation of obesity and insulin resistance by the iron chelator DFO may be due in part to direct or indirect DFO-mediated regulation of iron, glucose and lipid metabolism. Thus, this iron chelator should be considered as a potential therapeutic agent in obesity. However, the clinical use of DFO for obesity might be limited because of its known side-effects including systemic metal ion depletion after long-term treatment (53), but above that because some of the obese children might be more prone to iron deficiency $(28,29)$. Further studies on the involvement of iron metabolic alterations in adipose tissue might provide new approaches for better obesity control.

\section{Declaration of interest}

The authors declare that there is no conflict of interest that could be perceived as prejudicing the impartiality of the research reported.

\section{Funding}

This work did not receive any specific grant from any funding agency in the public, commercial, or not-for-profit sector.

\section{Acknowledgements}

This study was funded by the Student's Platform for Innovation and Entrepreneurship Training Program (170104). The work was also supported by the Natural Science Foundation of China (U1608282, 81430025, 81600941).

\section{References \\ 1 Kubota T, Kubota N \& Kadowaki T. Imbalanced insulin actions in obesity and type 2 diabetes: key mouse models of insulin signaling pathway. Cell Metabolism 201725 797-810. (https://doi. org/10.1016/j.cmet.2017.03.004) \\ 2 Azzini E, Giacometti J \& Russo GL. Antiobesity effects of anthocyanins in preclinical and clinical studies. Oxidative}

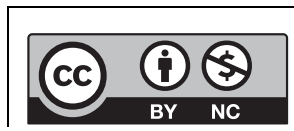

This work is licensed under a Creative Commons Attribution-NonCommercial 4.0 International License. 
Medicine and Cellular Longevity 20172017 2740364. (https://doi. org/10.1155/2017/2740364)

3 McCurley JL, Crawford MA \& Gallo LC. Prevention of type 2 diabetes in U.S. hispanic youth: a systematic review of lifestyle interventions. American Journal of Preventive Medicine 201753 519-532. (https://doi. org/10.1016/j.amepre.2017.05.020)

4 Ji Q. Treatment strategy for type 2 diabetes with obesity: focus on glucagon-like peptide-1 receptor agonists. Clinical Therapeutics 2017 39 1244-1264. (https://doi.org/10.1016/j.clinthera.2017.03.013)

5 Fernandez-Real JM, Lopez-Bermejo A \& Ricart W. Cross-talk between iron metabolism and diabetes. Diabetes 200251 2348-2354. (https:// doi.org/10.2337/diabetes.51.8.2348)

6 Jehn M, Clark JM \& Guallar E. Serum ferritin and risk of the metabolic syndrome in U.S. adults. Diabetes Care 200427 2422-2428. (https://doi.org/10.2337/diacare.27.10.2422)

7 Qi L, van Dam RM, Rexrode K \& Hu FB. Heme iron from diet as a risk factor for coronary heart disease in women with type 2 diabetes. Diabetes Care 200730 101-106. (https://doi.org/10.2337/dc06-1686)

8 Orr JS, Kennedy A, Anderson-Baucum EK, Webb CD, Fordahl SC, Erikson KM, Zhang Y, Etzerodt A, Moestrup SK \& Hasty AH. Obesity alters adipose tissue macrophage iron content and tissue iron distribution. Diabetes 201463 421-432. (https://doi.org/10.2337/ db13-0213)

9 Tajima S, Ikeda Y, Sawada K, Yamano N, Horinouchi Y, Kihira Y, Ishizawa K, Izawa-Ishizawa Y, Kawazoe K, Tomita S, et al. Iron reduction by deferoxamine leads to amelioration of adiposity via the regulation of oxidative stress and inflammation in obese and type 2 diabetes KKAy mice. American Journal of Physiology: Endocrinology and Metabolism 2012302 E77-E86. (https://doi.org/10.1152/ ajpendo.00033.2011)

10 Xue H, Chen D, Zhong YK, Zhou ZD, Fang SX, Li MY \& Guo C. Deferoxamine ameliorates hepatosteatosis via several mechanisms in ob/ob mice. Annals of the New York Academy of Sciences 20161375 52-65. (https://doi.org/10.1111/nyas.13174)

11 Moreno-Navarrete JM, Novelle MG, Catalan V, Ortega F, Moreno M, Gomez-Ambrosi J, Xifra G, Serrano M, Guerra E, Ricart W, et al. Insulin resistance modulates iron-related proteins in adipose tissue. Diabetes Care 201437 1092-1100. (https://doi.org/10.2337/dc131602)

12 Gotardo EM, dos Santos AN, Miyashiro RA, Gambero S, Rocha T, Ribeiro ML \& Gambero A. Mice that are fed a high-fat diet display increased hepcidin expression in adipose tissue. Journal of Nutritional Science and Vitaminology 201359 454-461. (https://doi.org/10.3177/ jnsv.59.454)

13 Sherman AR. Lipogenesis in iron-deficient adult rats. Lipids 197813 473-478. (https://doi.org/10.1007/BF02533616)

14 Gabrielsen JS, Gao Y, Simcox JA, Huang J, Thorup D, Jones D, Cooksey RC, Gabrielsen D, Adams TD, Hunt SC, et al. Adipocyte iron regulates adiponectin and insulin sensitivity. Journal of Clinical Investigation 2012122 3529-3540. (https://doi.org/10.1172/ JCI44421)

15 Moreno-Navarrete JM, Ortega F, Moreno M, Ricart W \& FernandezReal JM. Fine-tuned iron availability is essential to achieve optimal adipocyte differentiation and mitochondrial biogenesis. Diabetologia 201457 1957-1967. (https://doi.org/10.1007/s00125-014-3298-5)

16 Cooksey RC, Jones D, Gabrielsen S, Huang J, Simcox JA, Luo B, Soesanto Y, Rienhoff H, Abel ED \& McClain DA. Dietary iron restriction or iron chelation protects from diabetes and loss of betacell function in the obese (ob/ob lep-/-) mouse. American Journal of Physiology: Endocrinology and Metabolism 2010298 E1236-E1243. (https://doi.org/10.1152/ajpendo.00022.2010)

17 Valenti L, Fracanzani AL, Dongiovanni P, Bugianesi E, Marchesini G, Manzini P, Vanni E \& Fargion S. Iron depletion by phlebotomy improves insulin resistance in patients with nonalcoholic fatty liver disease and hyperferritinemia: evidence from a case-control study.
American Journal of Gastroenterology 2007102 1251-1258. (https:// doi.org/10.1111/j.1572-0241.2007.01192.x)

18 Dongiovanni P, Fracanzani AL, Fargion S \& Valenti L. Iron in fatty liver and in the metabolic syndrome: a promising therapeutic target. Journal of Hepatology 201155 920-932. (https://doi.org/10.1016/j. jhep.2011.05.008)

19 Houschyar KS, Ludtke R, Dobos GJ, Kalus U, Broecker-Preuss M, Rampp T, Brinkhaus B \& Michalsen A. Effects of phlebotomy-induced reduction of body iron stores on metabolic syndrome: results from a randomized clinical trial. BMC Medicine 201210 54. (https://doi. org/10.1186/1741-7015-10-54)

20 Hosogai N, Fukuhara A, Oshima K, Miyata Y, Tanaka S, Segawa K, Furukawa S, Tochino Y, Komuro R, Matsuda M, et al. Adipose tissue hypoxia in obesity and its impact on adipocytokine dysregulation. Diabetes 200756 901-911. (https://doi.org/10.2337/db06-0911)

21 Halberg N, Khan T, Trujillo ME, Wernstedt-Asterholm I, Attie AD, Sherwani S, Wang ZV, Landskroner-Eiger S, Dineen S, Magalang UJ, et al. Hypoxia-inducible factor 1alpha induces fibrosis and insulin resistance in white adipose tissue. Molecular and Cellular Biology 2009 29 4467-4483. (https://doi.org/10.1128/MCB.00192-09)

22 Pasarica M, Rood J, Ravussin E, Schwarz JM, Smith SR \& Redman LM. Reduced oxygenation in human obese adipose tissue is associated with impaired insulin suppression of lipolysis. Journal of Clinical Endocrinology and Metabolism 201095 4052-4055. (https://doi. org/10.1210/jc.2009-2377)

23 Zhang X, Lam KS, Ye H, Chung SK, Zhou M, Wang Y \& Xu A. Adipose tissue-specific inhibition of hypoxia-inducible factor 1 alpha\} induces obesity and glucose intolerance by impeding energy expenditure in mice. Journal of Biological Chemistry 2010285 32869-32877. (https://doi.org/10.1074/jbc.M110.135509)

24 Norouzirad R, Gonzalez-Muniesa P \& Ghasemi A. Hypoxia in obesity and diabetes: potential therapeutic effects of hyperoxia and nitrate. Oxidative Medicine and Cellular Longevity 201720175350267. (https://doi.org/10.1155/2017/5350267)

25 Guo C, Zhang YX, Wang T, Zhong ML, Yang ZH, Hao LJ, Chai R \& Zhang S. Intranasal deferoxamine attenuates synapse loss via up-regulating the P38/HIF-1alpha pathway on the brain of APP/PS1 transgenic mice. Frontiers in Aging Neuroscience 20157 104. (https:// doi.org/10.3389/fnagi.2015.00104)

26 Kaplan ML, Trout JR \& Leveille GA. Adipocyte size distribution in $\mathrm{ob} / \mathrm{ob}$ mice during preobese and obese phases of development.. Proceedings of the Society for Experimental Biology and Medicine 1976 153 476-482. (https://doi.org/10.3181/00379727-153-39572)

27 Carpentier JL, Perrelet A \& Orci L. Perturbation of the adipose cell plasma membrane in obese (ob/ob) mice. Laboratory Investigation 197737 260-264.

28 Kennedy ML, Failla ML \& Smith JC Jr. Influence of genetic obesity on tissue concentrations of zinc, copper, manganese and iron in mice. Journal of Nutrition 1986116 1432-1441. (https://doi.org/10.1093/ jn/116.8.1432)

29 Failla ML, Kennedy ML \& Chen ML. Iron metabolism in genetically obese (ob/ob) mice. Journal of Nutrition 1988118 46-51. (https://doi. org/10.1093/jn/118.1.46)

30 Ma X, Lee P, Chisholm DJ \& James DE. Control of adipocyte differentiation in different fat depots; implications for pathophysiology or therapy. Frontiers in Endocrinology 201561. (https://doi.org/10.3389/fendo.2015.00001)

31 Gao Y, Li Z, Gabrielsen JS, Simcox JA, Lee SH, Jones D, Cooksey B, Stoddard G, Cefalu WT \& McClain DA. Adipocyte iron regulates leptin and food intake. Journal of Clinical Investigation $2015 \mathbf{1 2 5}$ 3681-3691. (https://doi.org/10.1172/JCI81860)

32 Sutherland LN, Bomhof MR, Capozzi LC, Basaraba SA \& Wright DC. Exercise and adrenaline increase PGC-1\{alpha\} mRNA expression in rat adipose tissue. Journal of Physiology 2009587 1607-1617. (https:// doi.org/10.1113/jphysiol.2008.165464) http://www.endocrineconnections.org

https://doi.org/10.1530/EC-18-0054 (c) 2018 The authors

Published by Bioscientifica Ltd
This work is licensed under a Creative Commons Attribution-NonCommercial 4.0 International License. 
33 Tiraby C, Tavernier G, Lefort C, Larrouy D, Bouillaud F, Ricquier D \& Langin D. Acquirement of brown fat cell features by human white adipocytes. Journal of Biological Chemistry 2003278 33370-33376. (https://doi.org/10.1074/jbc.M305235200)

34 Larter CZ \& Yeh MM. Animal models of NASH: getting both pathology and metabolic context right. Journal of Gastroenterology and Hepatology 200823 1635-1648. (https://doi.org/10.1111/j.14401746.2008.05543.x)

35 Simcox JA \& McClain DA. Iron and diabetes risk. Cell Metabolism 201317 329-341. (https://doi.org/10.1016/j.cmet.2013.02.007)

36 Huang J, Jones D, Luo B, Sanderson M, Soto J, Abel ED, Cooksey RC $\&$ McClain DA. Iron overload and diabetes risk: a shift from glucose to fatty acid oxidation and increased hepatic glucose production in a mouse model of hereditary hemochromatosis. Diabetes 201160 80-87. (https://doi.org/10.2337/db10-0593)

37 Dongiovanni P, Ruscica M, Rametta R, Recalcati S, Steffani L, Gatti S, Girelli D, Cairo G, Magni P, Fargion S, et al. Dietary iron overload induces visceral adipose tissue insulin resistance. American Journal of Pathology 2013182 2254-2263. (https://doi.org/10.1016/j. ajpath.2013.02.019)

38 Tchetina EV, Markova GA, Poole AR, Zukor DJ, Antoniou J, Makarov SA \& Kuzin AN. Deferoxamine suppresses collagen cleavage and protease, cytokine, and COL10A1 expression and upregulates AMPK and Krebs cycle genes in human osteoarthritic cartilage. International Journal of Rheumatology 20162016 6432867. (https:// doi.org/10.1155/2016/6432867)

39 Rumberger JM, Peters T Jr, Burrington C \& Green A. Transferrin and iron contribute to the lipolytic effect of serum in isolated adipocytes. Diabetes 200453 2535-2541. (https://doi.org/10.2337/ diabetes.53.10.2535)

40 Tanner LI \& Lienhard GE. Insulin elicits a redistribution of transferrin receptors in 3T3-L1 adipocytes through an increase in the rate constant for receptor externalization. Journal of Biological Chemistry $19872628975-8980$

41 Lee P, Peng H, Gelbart T, Wang L \& Beutler E. Regulation of hepcidin transcription by interleukin-1 and interleukin-6. PNAS $2005 \mathbf{1 0 2}$ 1906-1910. (https://doi.org/10.1073/pnas.0409808102)

42 Luciani N, Brasse-Lagnel C, Poli M, Anty R, Lesueur C, Cormont M, Laquerriere A, Folope V, LeMarchand-Brustel Y, Gugenheim J, et al. Hemojuvelin: a new link between obesity and iron homeostasis. Obesity 201119 1545-1551. (https://doi.org/10.1038/oby.2011.12)

43 Fernandez-Real JM, McClain D \& Manco M. Mechanisms linking glucose homeostasis and iron metabolism toward the onset and progression of type 2 diabetes. Diabetes Care 201538 2169-2176. (https://doi.org/10.2337/dc14-3082)

44 Nemeth E, Tuttle MS, Powelson J, Vaughn MB, Donovan A, Ward DM, Ganz T \& Kaplan J. Hepcidin regulates cellular iron efflux by binding to ferroportin and inducing its internalization. Science 2004306 2090-2093. (https://doi.org/10.1126/science.1104742)

45 Ray PD, Huang BW \& Tsuji Y. Reactive oxygen species (ROS) homeostasis and redox regulation in cellular signaling. Cellular Signalling 201224 981-990. (https://doi.org/10.1016/j. cellsig.2012.01.008)

46 Jager J, Gremeaux T, Cormont M., Le Marchand-Brustel Y \& Tanti JF. Interleukin-1beta-induced insulin resistance in adipocytes through down-regulation of insulin receptor substrate-1 expression. Endocrinology 2007148 241-251. (https://doi.org/10.1210/en.2006-0692)

47 Potashnik R, Kozlovsky N, Ben-Ezra S, Rudich A \& Bashan N. Regulation of glucose transport and GLUT-1 expression by iron chelators in muscle cells in culture. American Journal of Physiology 1995269 E1052-E1058. (https://doi.org/10.1152/ ajpendo.1995.269.6.E1052)

48 Jiang C, Qu A, Matsubara T, Chanturiya T, Jou W, Gavrilova O, Shah YM \& Gonzalez FJ. Disruption of hypoxia-inducible factor 1 in adipocytes improves insulin sensitivity and decreases adiposity in high-fat diet-fed mice. Diabetes 201160 2484-2495. (https://doi. org/10.2337/db11-0174)

49 Chen J, Gu Z, Wu M, Yang Y, Zhang J, Ou J, Zuo Z, Wang J \& Chen Y. $\mathrm{C}$-reactive protein can upregulate VEGF expression to promote ADSC-induced angiogenesis by activating HIF-1alpha via CD64/ PI3k/Akt and MAPK/ERK signaling pathways. Stem Cell Research and Therapy 20167 114. (https://doi.org/10.1186/s13287-016-0377-1)

50 Arany Z, Foo SY, Ma Y, Ruas JL, Bommi-Reddy A, Girnun G, Cooper M, Laznik D, Chinsomboon J, Rangwala SM, et al. HIF-independent regulation of VEGF and angiogenesis by the transcriptional coactivator PGC-1alpha. Nature 2008451 1008-1012. (https://doi.org/10.1038/nature06613)

51 O'Hagan KA, Cocchiglia S, Zhdanov AV, Tambuwala MM, Cummins EP, Monfared M, Agbor TA, Garvey JF, Papkovsky DB, Taylor CT, et al. PGC-1alpha is coupled to HIF-1alpha-dependent gene expression by increasing mitochondrial oxygen consumption in skeletal muscle cells. PNAS 2009106 2188-2193. (https://doi. org/10.1073/pnas.0808801106)

52 Pino E, Wang H, McDonald ME, Qiang L \& Farmer SR. Roles for peroxisome proliferator-activated receptor gamma (PPARgamma) and PPARgamma coactivators 1alpha and 1beta in regulating response of white and brown adipocytes to hypoxia. Journal of Biological Chemistry 2012287 18351-18358. (https://doi.org/10.1074/jbc. M112.350918)

53 Kontoghiorghe CN \& Kontoghiorghes GJ. Efficacy and safety of ironchelation therapy with deferoxamine, deferiprone, and deferasirox for the treatment of iron-loaded patients with non-transfusiondependent thalassemia syndromes. Drug Design, Development and Therapy 201610 465-481. (https://doi.org/10.2147/DDDT.S79458)
Received in final form 13 March 2018 Accepted 27 March 2018 http://www.endocrineconnections.org https://doi.org/10.1530/EC-18-0054 (c) 2018 The authors Published by Bioscientifica Ltd

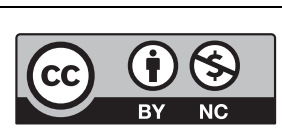

This work is licensed under a Creative Commons Attribution-NonCommercial 4.0 International License. 